\title{
Developing Life-Based Speaking Syllabus for Librarians in A Blended Learning Platform
}

\author{
Nur Mukminatien \\ English Department, Faculty of Letters \\ Universitas Negeri Malang \\ Malang, Indonesia \\ nur.mukminatien.fs@um.ac.id
}

\begin{abstract}
This paper presents a procedure of developing a Speaking syllabus for librarians designed for a blended learning (BL) platform, a combination between face to face and online format. Considering that the syllabus is designed for developing learners' oral competence, the target speaking skill is directed for developing learners' ability to perform effective communication in their workplace and daily lives as well, and so the topics/themes are selected for the librarians' needs. This is in line with life-based learning by using Content Language Integrated Learning (CLIL) approach. For this purpose, the syllabus development starts with needs analysis, topic selection, and syllabus prototype development, expert evaluation, and revision for final product. The syllabus is structured in such a way that the learning experience is explicitly stated for two formats: classroom face-to face and online to ensure that $B L$ is purposefully planned for instructional activities. The online materials will make learners learn in a flexible time for independent study and for structured assignment.
\end{abstract}

\section{Keywords-Blended learning, CLIL, Speaking syllabus}

\section{INTRODUCTION}

Blended learning (BL) has become well-known in English language teaching due to its advantages that provide learners with many possible learning activities in and outside the classroom. The combination between face to face and online format makes learning more flexible in terms of learning time and learners' preferences. This technology-based learning emerges because of the availability of the Internet access. Dudeney and Hockly suggest that English teachers make use of technology so that learners will have a lot of opportunities to be exposed to English from many different kinds of texts and media both offline and online [1]. Obviously, to make teaching and learning process more effective and efficient, BL is a good choice to solve the problem of limited time of learning in a conventional schedule where learning usually can only take place in the classroom. BL can also make learners learn English independently and give them the opportunity to arrange their time to study based on their available time [2], [3].

In its implementation, technology based language learning varies in types. Tomlinson and Whitaker summarized BL from Smith and Kurthen cited by Gruba dan Hinkelman into four types: web-enhanced, blended, hybrid, and fully online [2]. Web-enhanced learning (WL) refers to learning activities by using a minimum amount of technology for online learning less than $45 \%$ compared to the face to face, while blended learning (BL) is a learning experience by employing online learning of around $45 \%-80 \%$ whereas fully online is a learning activity which is mostly online ( $>80 \%$ ). Based on the taxonomy, BL is the kind of learning platform that uses online learning ranging from $45 \%-80 \%$ of the total planned learning time.

Consequently, it is suggested that students be prepared for becoming multimedia literate so that they have adequate skills for learning in multimedia based environment. The meaning of being literate is now different from that in the conventional education. In the conventional education, being literate, or having literacy competence referred to the ability to read and write referring to print materials, while now the definition is broadened to cover not only the ability to read and write print texts but also non-print. Therefore, literacy is part and the responsibility of education in general. Cox, states that education should make learners able to find meaning and to communicate effectively using multimedia tools, and learn about and with multimedia [4]. Learning experience using multimedia modes would develop students' multimedialiteracy competence [5], [6]. In short, information that reaches education in many different kinds of mode has made learning English more practical and flexible in terms of providing a choice of learning experiences suitable for learners' needs and preferences.

As a result of technology advancement, a lot of learning innovation has been made by English teachers in Indonesian context in the forms of many different kinds of learning experience. Take for example, a reading class discussing a topic about the danger of smoking was successfully conducted by Kurniawati in her classroom action research [7]. In the prereading activity, the students watched a video clip containing relevant information to the reading passage, about different kinds of cigarette-related diseases. This activity was successful in helping learners activate their background knowledge and understand the information in the reading passage more easily. Another innovation was made by Asri where she used classroom blog for writing assessment [8]. In her writing class, students uploaded their work to get peer feedback and teacher 
feedback for improvement. Such online feedback was effective to improve students' writing quality.

Technology-supported innovation has contributed a lot in improving the quality of learning English, including the implementation of BL. Banados, developed a teaching model in the study entitled A Blended Learning Pedagogical Model for Teaching and Learning EFL Successfully through an online Interactive Multimedia Environment [9]. This BL model was successful in helping learners develop their proficiency. The learning experience covered many different kinds of activities in the forms of (1) independent learning, (2) face to face learning (3) online learning, and (4) communication with native speakers once a week. The innovation was effective in developing learners' proficiency. The BL program integrated its focus on giving learners the opportunity to learn authentic communication by assigning them to communicate with native speakers. Miyazoe and Anderson implemented three formats of online writing class in university level through forum, blog, and wikis by adopting constructivistic-reflective and collaborative learning [10]. The BL, implemented with three formats, was effective in making learners able to identify English writing style. In addition, learners showed positive attitude in the implementation. They stated that the learning activity was challenging and fun as well. Using multimedia in a writing class was implemented by Liu [11]. This experimental research showed an achievement difference between the experimental and the control group although statistically the difference was not significant. However, the qualitative analysis showed that such multimedia learning experiences made a positive change in learning situations from "have to learn" situation into "willing to learn" situation. It can be concluded that such learning approach is successful in providing more interesting learning situation.

Experimental research conducted by Ferriman is also another significant evidence of the effectiveness of BL [12]. It was directed to find out the effect of BL on students' ability in writing an essay in Thailand. The experimental group achieved higher score than the control group although statistically the difference was not significant. In fact, however, the use of bulletin board in the implementation was helpful in solving the problem of a big class size.

A good example of English course for librarians has been reported by Fontanin [13]. The English training program was conducted using in-service blended learning experience. The program got a positive response from the librarians. The learning activities cover reading comprehension, speaking including a discussion and describing library services, and listening activities from podcast. Writing program develops learners to prepare them to participate in an international conference. All of the-multimedia based activities were successful in developing the librarians' English proficiency and making the librarians have more opportunity to learn English without leaving their work.

Based on the nature of BL and evidence of the advantages of its implementation, it is obvious that BL has significant contribution in English classes to make learning more effective, efficient, and fun. It can also provide learners with more exposures of English beyond classroom environment. So, the online learning, in addition to face to face format, is suitable for solving the problem of the limitation of teaching English.

The implementation of BL in the multimedia environment is ideally designed based on a syllabus that is made in such a way that the recommended learning experiences are clearly and explicitly designed in the two different formats: online and offline/face-to-face. Tomlinson suggests that the spectrum of learning experience should be clear in terms of what activity is prepared for face to face and which one is for online [14]. It should be organized by considering the principles and tasks in the context of language learning and its conceptual framework. In the era of modern technology, it is evident teachers and learners have more opportunity to be exposed to English texts in many different kinds of mode. In addition, teachers are given the opportunity to suit their method and materials based on the students' need. BL makes it possible for teachers to accommodate the needs of learning format variations to meet the learners' need. Also, integrating many learning sources and giving many kinds of learning experiences in a number of conducive learning environments helps learners interact and develop knowledge and skills optimally [3]. To conclude, utilizing technology makes learning more efficient and effective.

To support teaching English using BL platform, a wellorganized syllabus should be prepared. Syllabus is part of a course design which is important as a basis for developing materials and the planned activities. To begin with, it is necessary to define the two terms, or the difference between Course Design and Syllabus. A Course design (CD), is a system of developing a course with a framework comprising several steps: (1) assessing needs, (2) formulating goals and objectives, (3) developing materials, (4) designing an assessment plan, (5) organizing the course, and (6) conceptualizing content [15]. In other words, a CD is a system of instructional Design while a syllabus is one of the products of $\mathrm{CD}$. Besides a syllabus, the product of $\mathrm{CD}$ may cover the materials (modules, worksheets, or textbook), and a set of assessment instruments. CD is a system because planning for one component will influence all the others. For example, planning the goal of a course will influence the kinds of instructional materials and assessment instruments.

The term syllabus, as a product, is usually used without the word design, while the process is called course design. A syllabus is a description of all aspects of the plan, implementation and evaluation of a course in an educational program (it should include the intention of the planners covering actual experiences of the pupils and the organization [16]. However, when a term syllabus design is found in a textbook, it refers to a process in the system of development as used [17].

This paper presents a model of a procedure to develop a speaking syllabus for librarians using CLIL (Content Language Integrated Learning) approach designed for Blended Learning (BL) platform. It is defined as a syllabus for developing speaking ability for librarians by accommodating the content of the syllabus that meets the need of librarians for professional competence. Basically, the syllabus can also be used by students of Library Science Department to facilitate them with 
communication skills considered as a pre-service training course. CLIL which was introduced by Dale and Tanner [18], and Coyle and Marsh [19], is appropriate for this purpose. Grayston and Smith state that this move of language teaching approach has been claimed to be challenging to "bring together the insight of language teaching and a content teaching into a coherent goal" [20]. The content of the syllabus, in this case the topic/theme and/or language functions, are selected for librarians by considering what types of language functions and/or subject matter knowledge will be integrated into the language activities. Basically, CLIL is similar to Krahnke's idea about Content based English Syllabus (CBES), which refers to English syllabus where the language activities are suited with the subject matter knowledge of the students' need [21]. It can also be associated with ESP (English for Specific purposes) the implementation of which is CBES. So far, ESP has led to the production of a lot of specifically developed materials for many kinds of subject matter knowledge such as English for hotels and tourism, English for nursing, English for medical science, English for Biology, English for engineering, and many others, but English for librarians are difficult to find in the bookstore in Indonesia. Instead, teachers usually prepare their own materials compiled from many different sources.

This model of syllabus development can be used as an alternative in developing a Speaking syllabus not only for librarians as an in-service training, but also for students of Library Science Department as a pre-service training offered in the formal curriculum. It is expected that this model can be useful for teachers of English for specific purposes where theme and content should be carefully considered to meet the learners' professional need.

\section{METHOD OF DEVELOPMENT}

The syllabus is developed by employing R\&D (Research and development) in a more practical way [22]. The procedures of the Syllabus development employ five stages: (1) needs analysis, (2) topic selection, (3) content map for syllabus prototype development, (4) expert evaluation, and (5) revision for final product. This procedure of development is selected as an alternative to develop a speaking syllabus because it is believed to be appropriate for fulfilling librarians' professional need. This model can be used as a basis for developing materials specifically designed for them in a BL platform. The blended learning platform is suitable for librarians since it can make them develop their speaking ability without leaving their work. The following is a brief description of the procedures for each stage.

\section{A. Need Analysis}

To identify what the learners need, it is important to consider that a librarian is profession that makes them meet a lot of people in the library. Therefore, they need to be facilitated to learn to communicate in English to serve guests who cannot speak Indonesian, or it is important to present a topic in an international forum for professional development. The instrument for need analysis was in the form of online questionnaire. In this case, after their need was identified, topic selection (stage2) is done by considering the data in the need analysis and added by theoretical review.

\section{B. Topic Selection}

To select materials, Bao, suggests that materials (in this paper, it refers to core materials in a syllabus) be selected to accommodate the need of the target users by conducting the following procedure [14]: (1) conceptualizing learner needs, (2) translating subject matter and communication situation, (3) identifying verbal communication strategies, (4) utilizing verbal sources from real life, and (5) designing skill-acquiring activities. Stage one can be in the form of understanding who the learners are, and then followed by stage two, that is, translating the content and communication situations they will experience. Stage three deals with communication strategies needed, usually called interaction strategies, while stage four means utilizing real-life samples of language, not artificial ones, and stage five is designing tasks for the acquisition of the speaking skills, after an outline of communication and its components are selected based on the results of the questionnaire. In summary, determining the content of the syllabus in the form of core materials is very important as a guideline for syllabus development.

\section{Content Map for Syllabus Prototype Development}

After selecting suitable core materials and the components (sample of utterances/expressions, grammar exercises, and vocabulary), the content map is made before developing the syllabus. The following is an example of developing the content map as a blue print of the syllabus. A lists of language functions needed for students from the results of the questionnaire was used as the core materials [6]. It begins with formulating the goal of the speaking course.

\section{Goal}

This course develops the students' ability in expressing ideas fluently, correctly, confidently with acceptable and comprehensible pronunciation, stress, and intonation, in different situations and different language functions for everyday communication in the form of a conversation (dialog) or monolog concerning common activities in a library and daily life in general.

After the goal has been formulated, as the standard of achievement, (in one semester course), the content map is developed as shown in Table 1 as an example of a blue print of the syllabus. 
TABLE I. CONTENT MAP OF SPEAKING MATERIALS FOR LibRARIANS

\begin{tabular}{|c|c|c|c|}
\hline Unit & Situation & $\begin{array}{l}\text { Language } \\
\text { Function }\end{array}$ & $\begin{array}{c}\text { Expressions (Language } \\
\text { features) }\end{array}$ \\
\hline 1 & $\begin{array}{l}\text { In a reception } \\
\text { desk. A new } \\
\text { foreign } \\
\text { student wants } \\
\text { to become a } \\
\text { library } \\
\text { member. }\end{array}$ & $\begin{array}{l}\text { Asking for and } \\
\text { giving assistance } \\
\text { to foreign visitors } \\
\text { Telling visitors } \\
\text { how to become a } \\
\text { library member. }\end{array}$ & $\begin{array}{l}\text { A:Good morning. Can I } \\
\text { help you? } \\
\text { B:Yes, please. } \\
\text { A: I am a new student } \\
\text { here. Can you tell me how } \\
\text { to become a member? } \\
\text { A: Oh, sure. Please fill } \\
\text { out this form, first. (after } \\
\text { a moment....) OK? Wait } \\
\text { for a minute (enter data in } \\
\text { the computer). Here you } \\
\text { are (Giving a member } \\
\text { card) } \\
\text { B: Thanks. Can I borrow } \\
\text { abook now? } \\
\text { A: Sure. Go to the } \\
\text { circulation desk over } \\
\text { there. } \\
\text { B: Thanks } \\
\text { A; My pleasure }\end{array}$ \\
\hline 2 & $\begin{array}{l}\text { In a hall, } \\
\text { welcoming a } \\
\text { group of } \\
\text { guests from a } \\
\text { foreign } \\
\text { university in } \\
\text { bench } \\
\text { marking } \\
\text { program }\end{array}$ & $\begin{array}{l}\text { Describng library } \\
\text { service } \\
\text { (Monolog) }\end{array}$ & $\begin{array}{l}\text { Good morning ladies and } \\
\text { gentlemen. Welcome to } \\
\text { our library. I'm going to } \\
\text { describe our library } \\
\text { service in this university. } \\
\text { This library has } 10.000 \\
\text { textbooks and } 450 \text { e-books } \\
\text { and ..... ect }\end{array}$ \\
\hline 3 & $\begin{array}{l}\text { In a deposit } \\
\text { room, a }{ }^{2} \quad{ }^{2} \text { conversation } \\
\text { between a } \\
\text { guest and a } \\
\text { staff member }\end{array}$ & $\begin{array}{l}\text { Asking for and } \\
\text { giving directions }\end{array}$ & $\begin{array}{l}\text { A: excuse me. Where is } \\
\text { the rest room? } \\
\text { B: Go straight ahead. } \\
\text { Turn right at the corner of } \\
\text { the manager room. The } \\
\text { toilet is on your left. } \\
\text { A: Thank you } \\
\text { B: Any time }\end{array}$ \\
\hline 4. & $\begin{array}{l}\text { In a seminar } \\
\text { room } \\
\text { (speaking in } \\
\text { public) }\end{array}$ & $\begin{array}{l}\text { Presenting a topic } \\
\text { in an } \\
\text { International } \\
\text { conference }\end{array}$ & $\begin{array}{l}\text { Good morning Ladies and } \\
\text { Gentlemen. My name is } \\
\text { Wahyuni. I am fom } \\
\text { Jakarta National Library. } \\
\text { My topic is "How to } \\
\text { develop an English } \\
\text { program for librarians as } \\
\text { an inserviece training. Etc }\end{array}$ \\
\hline
\end{tabular}

The content map describes relevant situations, language functions, and examples of expressions in a dialog. The list of situations and language functions can be continued according to the course design, which is usually designed for one semester. The results of needs analysis from the questionnaire would be the basis for syllabus development. When developing a prototype or a complete syllabus, more columns are needed to describe the format of learning in the learning experience column and the assessment procedures: online and face to face. (The example of content map in Table 1 contains only a sample of four situations of language use).

\section{E. Expert Evaluation}

Expert evaluation is necessary for validation of the syllabus. The prototype was reviewed by an expert for its validity. It deals with how the syllabus represents what is expected in the teaching of speaking. The evaluation instrument is in the form of a check list and feedback. The criteria are made on the basis of the suitability of language functions with the learners' need and the availability of expressions to learn (the sentence structure), the vocabulary, and practice for pronunciation, intonation, and stress. Overall language proficiency and suitability of the level of difficulty should be included in the syllabus because developing speaking ability means developing students' oral proficiency. Shumin, states that "language proficiency is a multifaceted modality, consisting various levels of ability and domains" [23].

\section{F. Revision of the Final Product}

The results of the check list and feedback (comments/suggestions) were used to improve the quality of the syllabus by revising the draft accordingly. After all of the revision process, the prototype of the syllabus is ready for implementation. This R\&D, however, only produced the content map for developing the prototype of Speaking Syllabus for librarians with no implementation results as a try-out evidence. So, basically it needs to be implemented for try-out to find evidence of the suitability, practicality, and feasibility of the syllabus before real implementation in a formal curriculum.

\section{CONCLUSION}

Based on the theoretical explanation, CLIL-Based Speaking syllabus is a syllabus designed for developing speaking ability for librarians, so the content (language functions) cover the needs of the librarians for their professional competence. This is an example of using CLIL in the syllabus development that is, integrating content in language activities to develop their communicative competence. Blended Learning (BL) is a platform of learning by combining face to face and online format that should be explicitly stated in the syllabus in the column of learning experience. Online learning makes it possible for learners to be exposed to "authentic" English use for communication. The language functions in the content map are those for professional communications and for daily life communication in a wider use. This makes the syllabus classified as life-based learning syllabus because learning to communicate for daily activities are available for learners.

The syllabus development procedures in the $R \& D$ are similar to materials development in nature, but the syllabus in this case functions as a guideline for developing materials. In the BL platform syllabus, an explicit description of recommended learning experience should be provided in a learning experience column to guide teachers how BL is implemented, and the assessment procedures to use as well.

As a matter of fact, considering that this $R \& D$ for the syllabus development has some limitations, some suggestions are addressed to practitioners for coming into a comprehensive product. Firstly, the syllabus draft should be implemented in a try-out session to find evidence of the applicability, suitability, and feasibility of the product before real implementation in the formal curriculum. Secondly, this paper contains only a content map of the syllabus; therefore, practitioners are suggested to develop their own syllabus based on the content map to adapt their specific needs. Finally, in the syllabus development, 
practitioners are recommended to write the types of learning experience covering both face-to-face and online learning activities.

\section{REFERENCES}

[1] G. Dudeney and N. Hockly, How to teach English with technology. Pearson - Longman, 2007.

[2] F. Mishan, "Demystifying Blended Learning," in Developing Materials for Language Teaching, 2nd ed., London: Bloomsbury, 2013.

[3] A. Littlejohn and C. Pegler, Preparing for Blended e-Learning. London: Routledge, 2007.

[4] C. Cox, Teaching Language Arts. A Student-and Response-Centered Classroom. Boston: Allyn and Bacon, 1996.

[5] N. Mukminatien, "Providing Multiple Media Form Experiences in a Reading Comprehension Class," in 47th RELC International Conference, 2012.

[6] N. Mukminatien, R. P. Yaniafari, and T. Kurniawan, "A Speaking Course Design Using CLIL Approach for Non-English Department Students," in iELT -CON 2017. 8th International English Language Teaching Conference. "The 21st Century Classroom: ELT Practices \& Innovations, 2017.

[7] Y. Kurniawati, "Improving The Students'Reading Comprehension Through Modified Think-Pair-Share Strategy," Universitas Negeri Malang, 2012.

[8] A. N. Asri, "Using Classroom Blog for Writing Assessment," Universitas Negeri Malang, 2009.

[9] E. Bañados, "A blended-learning pedagogical model for teaching and learning EFL successfully through an online interactive multimedia environment," Calico J., pp. 533-550, 2006.

[10] T. Miyazoe and T. Anderson, "Learning outcomes and students' perceptions of online writing: Simultaneous implementation of a forum, blog, and wiki in an EFL blended learning setting," System, vol. 38, no. 2, pp. 185-199, 2010.
[11] J. Liu, "An Experimental Study on the effectiveness of multimedia in College English Teaching," English Lang. Teach., vol. 3, no. 1, p. 191, 2010.

[12] N. Ferriman, "The impact of blended e-learning on undergraduate academic essay writing in English (L2)," Comput. Educ., vol. 60, no. 1, pp. 243-253, 2013.

[13] M. Fontanin, "Developing an English course for in-service librarians: The advantages of blended learning," Libr. Manag., vol. 29, no. 8/9, pp. 777-788, 2008.

[14] D. Bao, "Developing Materials for Speaking Skills," in Developing Materials for Language Teaching, 2nd ed., London: Bloomsbury, 2014.

[15] K. Graves and S. Xu, Designing language courses: A guide for teachers. Boston, MA: Heinle \& Heinle, 2000.

[16] D. Finney, "The ELT Curriculum: A Flexible Model for a Changing World," in Methodology in language teaching: An anthology of current practice, Cambridge: Cambridge University Press, 2002, pp. 69-79.

[17] J. C. Richards and W. A. Renandya, Methodology in Language Teaching. Cambridge: Cambridge University Press, 2002.

[18] L. Dale and R. Taner, CLIL Activities. A resource for subject and language teachers. Cambridge: Cambridge University Press, 2012.

[19] D. Coyle, P. Hood, and D. Marsh, Content and Language Integrated Learning. Cambridge: Cambridge University Press, 2010.

[20] S. Grayston and H. Smith, "Professional Development for ELT, CLIL and Content Teachers," in RELC International Conference, 2015.

[21] K. Krahnke, Approaches to Syllabus Design for Foreign Language Teaching. Language in Education: Theory and Practice, No. 67. Prentice-Hall, Inc., Book Distribution Center, Route 59 at Brook Mill Drive, West Nyack, NY 10994. West Nyack, New York: Prentice-Hall, 1987.

[22] W. R. Borg and M. D. Gall, Educational research: An introduction. New York \& London: Longman Publishing, 1983.

[23] K. Shumin, "Factors to consider: Developing adult EFL students' speaking abilities," Methodol. Lang. Teach. An Anthol. Curr. Pract., vol. 12, pp. 204-211, 2002. 